\title{
Differential Effects of Insulin Therapy on Hepatic and Peripheral Insulin Sensitivity in Type 2 (Non-Insulin-Dependent) Diabetes
}

\author{
A. Nankervis, J.Proietto, P.Aitken, M. Harewood and F. Alford \\ Endocrine Unit and Department of Medicine, University of Melbourne, St. Vincent's Hospital, Fitzroy, Victoria, Australia
}

\begin{abstract}
Summary. Hepatic glucose production and metabolic clearance rate of glucose were measured using $\left(3-{ }^{3} \mathrm{H}\right)$ glucose at steady state, basally and during two sequential $2 \mathrm{~h}$ insulin $(25$ and $\left.40 \mathrm{mU} \cdot \mathrm{kg}^{-1} \cdot \mathrm{h}^{-1}\right) /$ glucose $\left(2\right.$ and $3 \mathrm{mg} \cdot \mathrm{kg}^{-1} \cdot \mathrm{min}^{-1}$ ) infusion periods. Eight diabetic subjects were studied before and after 1 week of twice daily insulin therapy; six control subjects matched for age, weight and degree of obesity were also studied. In the diabetic patients, pre-treatment hepatic glucose production was $20.0 \pm 2.2,9.9 \pm 2.9$, and $1.4 \pm 0.8 \mu \mathrm{mol}$. $\mathrm{kg}^{-1} \cdot \mathrm{min}^{-1}$ respectively $( \pm$ SEM) for each of the three periods, and fell significantly with treatment to $12.8 \pm 1.7,4.0$ \pm 1.5 and $1.9 \pm 1.0 \mu \mathrm{mol} \cdot \mathrm{kg}^{-1} \cdot \mathrm{min}^{-1}$. Hepatic glucose production in normal subjects was $13.2 \pm 0.6,2.2 \pm 0.8$ and $<1 \mu \mathrm{mol} \cdot \mathrm{kg}^{-1} \cdot \mathrm{min}^{-1}$. The pre-treatment metabolic clearance rate in all diabetic studies with insulin levels $\geqslant 30 \mathrm{mU} / 1$ was $1.10 \pm 0.14 \mathrm{ml} \cdot \mathrm{kg}^{-1} \cdot \min ^{-1}$ and remained virtually unchanged following insulin therapy; this was significantly lower than in the control subjects $(6.83 \pm 1.02, p<0.001)$. Basal non-esterified fatty acid levels were higher $(p<0.02)$ in
\end{abstract}

the pre-treated diabetic patients compared to post-treated diabetic patients and control subjects. Non-esterified fatty acids in each group fell to similar levels during the insulin infusions, but the rate of fall was slower in the pre-treated diabetic patients. Insulin receptor binding to erythrocytes was normal in the diabetic subjects and unchanged by treatment. Therefore, following insulin treatment of uncontrolled Type 2 (non-insulin-dependent) diabetes, the initially increased basal hepatic glucose production, and decreased hepatic sensitivity, return towards normal. However, the glucose clearance remains low, despite good diabetic control, and appears to be a major factor in the continuing glucose intolerance. As insulin receptor binding is normal, the defect of glucose clearance in Type 2 diabetes appears compatible with a post-receptor defect of glucose metabolism.

Key words: Type 2 diabetes, hepatic glucose production, glucose utilization, metabolic clearance rate of glucose.
The mechanism of the glucose intolerance of diabetes is unclear. Whilst insulin deficiency is the predominant factor in the aetiology of Type 1 (insulin-dependent) diabetes, this is not the case for Type 2 (non-insulin-dependent) diabetes. In the latter, insulin resistance is believed to be a major factor in the genesis of the glucose intolerance $[1,2,3]$. However, studies of glucose kinetics in Type 2 diabetes have produced conflicting data concerning basal hepatic glucose production and basal glucose utilization, as well as the responses of these parameters to acute insulin administration. These differences in the literature may well be due to methodological problems in many of the earlier studies. In these earlier reports, basal hepatic glucose production has been reported as low [4], normal [5-7] and raised [8,9], with similarly confusing data for basal peripheral glucose utilization $[4,8$, 9]. Thus, there was no concensus as to the major cause of the glucose intolerance or the site of the insulin resistance, whether it be due to hepatic glucose over-produc- tion and/or decreased glucose clearance $[4,6,8,9]$. More recent studies in uncontrolled Type 2 diabetes have, however, suggested that basal hepatic glucose production is raised $[10,11]$ and that glucose clearance is markedly impaired [10]. Finally, the effect of a period of insulin treatment and good diabetic control on glucose kinetics in Type 2 diabetes has received little attention $[9,11]$. Answers to these questions are crucial to our understanding of overall glucose kinetics of the carbohydrate intolerance of Type 2 diabetes.

The aims of this study were to determine the site of insulin resistance in uncontrolled Type 2 diabetes, and to evaluate the effects of insulin therapy on glucose disposal. To this end, hepatic glucose production, glucose utilization and metabolic clearance rate of glucose were measured basally and during insulin infusions. These studies were subsequently repeated following a period of insulin therapy and good diabetic control. 
Table 1. Clinical and oral glucose tolerance test data of control and diabetic subjects

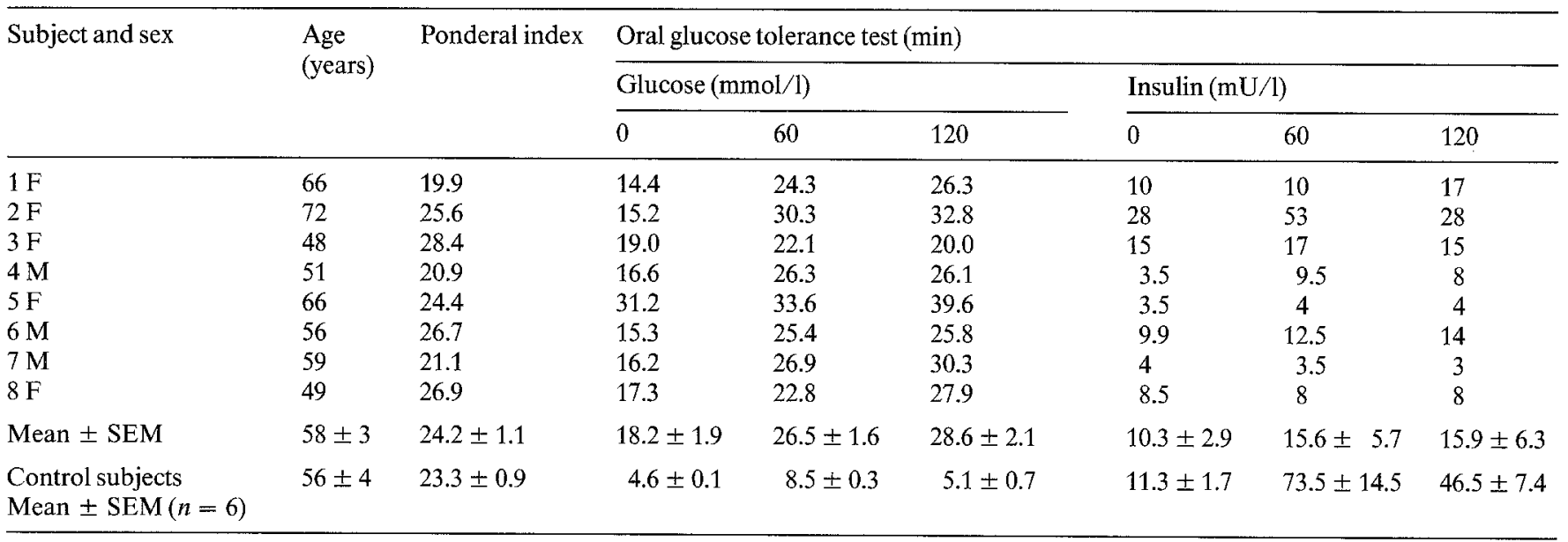

PROTOCOL

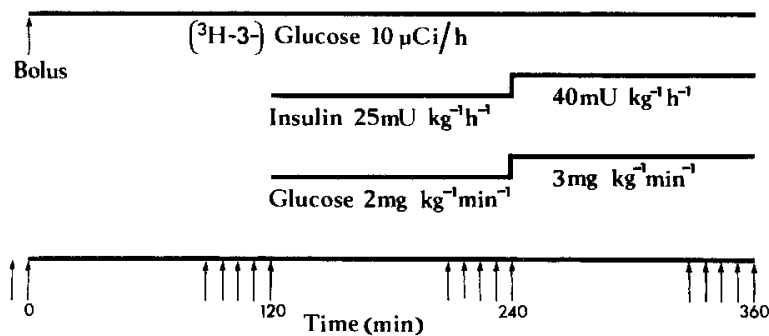

Fig. 1. Schematic diagram of the protocol used. The arrows indicate the sampling times

\section{Subjects and Methods}

\section{- Subjects}

Details of the subjects studied are shown in Table 1. Eight subjects (five women and three men, aged 48-72 years) were studied pre- and postinsulin therapy. Despite adequate diabetic diet (weight maintaining, with carbohydrate content varying from 120 to $200 \mathrm{~g}$ daily and comprising 40\%-50\% total caloric intake) and maximal doses of oral hypoglycaemic agents, all subjects had marked fasting hyperglycaemia (Table 1) and symptoms of poorly controlled diabetes mellitus, which necessitated admission to hospital for commencement of insulin therapy. The clinical characteristics of these subjects were typical of Type 2 diabetes in that the disease was longstanding ( $6.6 \pm 2$ years), previously controlled on oral agents, and with no episodes of ketoacidosis. Oral hypoglycaemic agents were ceased at least $72 \mathrm{~h}$ before the study, and no patient was receiving medication which could interfere with insulin or glucose metabolism at the time of study.

Following a 75 -g oral glucose tolerance test and the initial glucose kinetic study, the patient was commenced on a combination of highly purified neutral and isophane insulins given twice daily. The fasting blood glucose levels were maintained in the range $4-8 \mathrm{mmol} / \mathrm{l}$ and post-prandial blood glucose levels were $6-12 \mathrm{mmol} / 1$. A repeat study was performed at least 1 week later. On the morning before the repeat study, only crystalline pork insulin (Actrapid, Novo Research Institute, Copenhagen, Denmark) was administered and the evening dose withheld. Six healthy control subjects (three men and three women, aged 39-65 years, with no family history of diabetes) were also studied. Written informed consent was obtained from all control and diabetic subjects before their participation in the study. The protocol was approved by the Ethics and Research Committee of St. Vincent's Hospital, Melbourne.

\section{Experimental Procedures}

Figure 1 illustrates the protocol used. Subjects were studied after an overnight fast and a 60 -min period of recumbency. Solutions were infused through a $20 \mathrm{~cm}$ intracath placed in an antecubital vein, using a Gilson Minipuls II 4 channel pump (Gilson, Villiers-Le-Belle, France). Blood samples for estimation of $\left(3-{ }^{3} \mathbf{H}\right)$ glucose, total glucose, plasma insulin (IRI), plasma glucagon (IRG), ketone bodies and non-esterified fatty acids (NEFA) were collected at appropriate intervals (Fig. 1) through an indwelling butterfly needle placed in the contralateral dorsal hand vein. Basal hepatic glucose production was measured at steady state using a primed constant infusion of $\left(3-{ }^{3} \mathrm{H}\right)$ glucose (sp. act. $12 \cdot 3 \mathrm{Ci} / \mathrm{mmol}$ ) [12]. To hasten attainment of steady state, the glucose pool was appropriately primed by giving a $\left(3-{ }^{3} \mathrm{H}\right)$ glucose bolus at time zero varying between 15 and $35 \mu \mathrm{Ci}$, depending on the fasting blood glucose level (Sönksen P, personal communication), followed by a $\left(3 r^{3} \mathrm{H}\right)$ glucose infusion at a rate of $10 \mu \mathrm{Ci} / \mathrm{h}$. Steady state glucose turnover was further measured during insulin infusions at two dose levels ( 25 and $40 \mathrm{mU} \cdot \mathrm{kg}^{-1} \cdot \mathrm{h}^{-1}$ ). To prevent hypoglycaemia, glucose ( 2 and $3 \mathrm{mg} \cdot \mathrm{kg}^{-1} \cdot \mathrm{min}^{-1}$ respectively) was infused simultaneously [13]. Urine was collected for the last $60 \mathrm{~min}$ of each period for estimation of urinary glucose loss. At the conclusion of each study, two $5 \mathrm{~min}$ samples of the fluid delivered by the pumps for each period were collected into weighed tubes. From these were calculated the rates of infusion of $\left(3-{ }^{3} \mathrm{H}\right)$ glucose, unlabelled glucose and insulin [13]. To overcome the problem of insulin adsorbing to the IV tubing, insulin was run for $1 \mathrm{~h}$ before each study [14].

\section{Analytical Procedures}

Blood for all hormone estimations was promptly centrifuged, and the plasma stored at $-20^{\circ} \mathrm{C}$ until assayed. Blood for IRG estimations was collected into chilled heparinised tubes containing 5000 KIU Aprotinin (Trasylol, Bayer Pharmaceuticals, Botany, Australia). Plasma samples for measurement of $\left(3-{ }^{3} \mathrm{H}\right)$ glucose specific activity were deproteinated with $\mathrm{Ba}(\mathrm{OH})_{2}-\mathrm{ZnSO}_{4}$, and the supernatant divided into three aliquots for estimation of total glucose and $\left(3-{ }^{3} \mathrm{H}\right)$ glucose, as described previously $(13,15)$. The rate of $\left(3-{ }^{3} \mathrm{H}\right)$ glucose infusion was determined from the mean of three $0.1 \mathrm{ml}$ aliquots of the infusate collected at the end of each study. Total glucose was measured with a Centrifichem C400 analyser (Union Carbide Corporation, New York) using a hexokinase method. Plasma IRI and IRG were estimated by radioimmunoassay using dextran-charcoal separation of bound and free fractions $[14,16]$. Assay sensitivity for IRI was $1 \mathrm{mU} / 1$ with an interassay coefficient of variation at $10.5 \mathrm{mU} / 1$ of $6.3 \%$, and at $22.0 \mathrm{mU} / 1$ of $8.4 \%$. Assay sensitivity for IRG was $14 \mathrm{pg} / \mathrm{ml}$ with interassay coefficient of variation being $24 \%$ at $95 \mathrm{pg} / \mathrm{ml}$ and $454 \mathrm{pg} / \mathrm{ml}$. The IRG assay employed the pancreatic glucagon specific (C-Terminal reacting) antiserum RCS5 (kindly donated by Dr. S. R. Bloom, Hammersmith Hospital, London, UK), NEFA was measured by a manual colorimetric 
Table 2. Biochemical and glucose kinetic data of control and diabetic groups

\begin{tabular}{|c|c|c|c|c|}
\hline \multirow[t]{2}{*}{ Metabolic parameter } & \multirow[t]{2}{*}{ Study period } & \multicolumn{2}{|l|}{ Diabetic group } & \multirow[t]{2}{*}{ Control group } \\
\hline & & Pre-treatment & Post-treatment & \\
\hline Plasma glucose $(\mathrm{mmol} / \mathrm{l})$ & $\begin{array}{l}\text { Basal } \\
\text { Low dose } \\
\text { High dose }\end{array}$ & $\begin{array}{l}18.4 \pm 0.6 \\
18.9 \pm 1.1 \\
17.0 \pm 1.5\end{array}$ & $\begin{array}{l}14.1 \pm 0.6 \\
13.9 \pm 0.8 \\
12.7 \pm 1.5\end{array}$ & $\begin{array}{l}4.6 \pm 0.1 \\
5.1 \pm 0.6 \\
4.5 \pm 0.2\end{array}$ \\
\hline Plasma insulin (mU/l) & $\begin{array}{l}\text { Basal } \\
\text { Low dose } \\
\text { High dose }\end{array}$ & $\begin{aligned} 7 & \pm 1 \\
23 & \pm 2 \\
39 & \pm 2\end{aligned}$ & 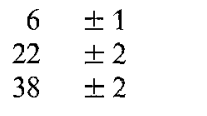 & 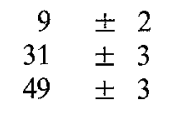 \\
\hline Plasma glucagon $(\mathrm{pg} / \mathrm{ml})$ & $\begin{array}{l}\text { Basal } \\
\text { Low dose } \\
\text { High dose }\end{array}$ & 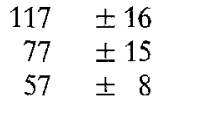 & 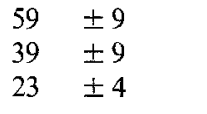 & 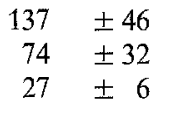 \\
\hline Hepatic glucose production $\left(\mu \mathrm{mol} \cdot \mathrm{kg}^{-1} \cdot \mathrm{min}^{-1}\right)$ & $\begin{array}{l}\text { Basal } \\
\text { Low dose } \\
\text { High dose }\end{array}$ & $\begin{array}{r}20.0 \pm 2.2 \\
9.9 \pm 2.9 \\
1.4 \pm 0.8\end{array}$ & $\begin{array}{r}12.8 \pm 1.7 \\
4.0 \pm 1.5 \\
1.9 \pm 1.0\end{array}$ & $\begin{array}{r}13.9 \pm 0.8 \\
1.8 \pm 1.0 \\
<1.0\end{array}$ \\
\hline Glucose utilization $\left(\mu \mathrm{mol} \cdot \mathrm{kg}^{-1} \cdot \min ^{-1}\right)$ & $\begin{array}{l}\text { Basal } \\
\text { Low dose } \\
\text { High dose }\end{array}$ & $\begin{array}{l}14.3 \pm 2.7 \\
17.0 \pm 2.2 \\
19.8 \pm 1.6\end{array}$ & $\begin{array}{l}11.4 \pm 1.8 \\
12.8 \pm 1.7 \\
14.4 \pm 1.5\end{array}$ & $\begin{array}{l}13.9 \pm 0.8 \\
16.9 \pm 2.2 \\
40.3 \pm 2.3\end{array}$ \\
\hline $\begin{array}{l}\text { Metabolic clearance rate of glucose } \\
\left(\mathrm{ml} \cdot \mathrm{kg}^{-1} \cdot \mathrm{min}^{-1}\right) \\
\text { Corresponding IRI }(\mathrm{mU} / \mathrm{l})\end{array}$ & $\begin{array}{l}\text { All studies with } \\
\text { IRI levels } \geqslant 30 \mathrm{mU} / 1\end{array}$ & $\begin{array}{l}1.10 \pm 0.14 \\
37 \quad \pm 2\end{array}$ & $\begin{array}{l}1.15 \pm 0.19 \\
40 \pm 2\end{array}$ & $\begin{array}{l}6.83 \pm 1.02 \\
44 \pm 3\end{array}$ \\
\hline Non-esterified fatty acid $(\mathrm{mmol} / \mathrm{l})$ & $\begin{array}{l}\text { Basal } \\
\text { Low dose } \\
\text { High dose }\end{array}$ & $\begin{array}{l}1.44 \pm 0.10 \\
0.66 \pm 0.17 \\
0.38 \pm 0.06\end{array}$ & $\begin{array}{l}1.03 \pm 0.10 \\
0.30 \pm 0.05 \\
0.30 \pm 0.07\end{array}$ & $\begin{array}{c}0.76 \pm 0.24 \\
0.33 \pm 0.16 \\
-\end{array}$ \\
\hline$\beta$-Hydroxybutyrate $(\mathrm{mmol} / \mathrm{l})$ & Basal & $0.98 \pm 0.46$ & $0.21 \pm 0.07$ & $0.06 \pm 0.01$ \\
\hline Erythrocyte receptor binding (basal \% binding) & & $8.98 \pm 1.07$ & $10.38 \pm 1.04$ & $9.3 \pm 0.35$ \\
\hline
\end{tabular}

Results expressed as mean \pm SEM; post-treatment studies were performed following 1 week of twice daily insulin therapy;

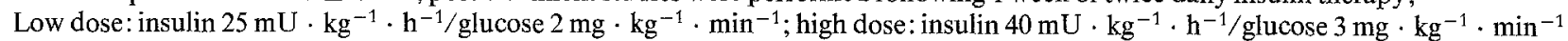

modification of a method of Carruthers and Young [17] and ketone bodies were estimated spectrophotometrically by the method of Williamson et al. [18]. Binding of ${ }^{125}$ I-insulin to human erythrocytes was measured using the method of Gambhir et al. [19].

\section{Calculations}

The rate of appearance of glucose $(\mathrm{Ra})$ at steady state was calculated from the formula $\mathrm{Ra}=\mathrm{F} / \mathrm{SA}$, where $\mathrm{F}$ is the rate of infusion of $\left(3-{ }^{3} \mathrm{H}\right)$ glucose and SA is the specific activity of the plasma $\left(3-{ }^{3} \mathrm{H}\right)$ glucose at steady state [20]. Steady state was defined as $<10 \%$ variation in the counts at plateau. The mean coefficient of variation of the plateau counts was $4.5 \pm 0.5 \%$ ( \pm SEM) for all studies. Subtraction of the amount of unlabelled glucose infused from the calculated total Ra gave the net hepatic glucose production for the insulin/glucose infusion periods. At steady state, plasma glucose was constant (the mean coefficient of variation of glucose plateau levels was $2.7 \pm 0.3 \%$ ) and therefore $\mathrm{Ra}$ equals the rate of disappearance of glucose. The rate of utilization of glucose was defined as the rate of disappearance of glucose minus the urinary glucose loss. The metabolic clearance rate of glucose was calculated as rate of utilization/plasma glucose [21]. Metabolic clearance rate of glucose has been previously validated as a measure of insulin mediated glucose uptake for IRI levels $>30 \mathrm{mU} / 1$ [22]. Therefore the metabolic clearance rate was calculated only when the plasma IRI was $>30 \mathrm{mU} / 1$. Statistical analyses were made using Student's t-test and linear regression analyses. All data are expressed as the mean \pm SEM.

\section{Results}

Table 1 shows the plasma glucose and insulin responses to the oral glucose load in the diabetic patients before insulin treatment compared with the mean values for the control group. Fasting blood glucose levels were significantly raised in all diabetic subjects $(p<0.001)$, but fasting insulin levels were similar to the control subjects (Table 1). Consistent with the severe glucose intolerance, the insulin responses obtained following the glucose load were markedly attenuated compared with the control group (Table $1 ; p<0.001$ ). The biochemical details of the glucose turnover studies of the diabetic subjects (pre- and post-insulin treatment) are given in Table 2, together with data for the control subjects. At steady state, the coefficient of variation of the mean plasma glucose and insulin concentrations at plateau was $<10 \%$ in all studies. Steady state glucose levels, basally and during the $25 \mathrm{mU} \cdot \mathrm{kg}^{-1} \cdot \mathrm{min}^{-1}$ (low) and $40 \mathrm{mU} \cdot \mathrm{kg}^{-1}$. $\mathrm{min}^{-1}$ (high) insulin infusion periods, were similar for each experimental group but both diabetic groups were hyperglycaemic, whereas the controls were euglycaemic (Table 2). The plateau insulin levels rose significantly in each study period for the three groups. The corresponding plateau IRI levels were similar for the three groups, except that the plateau IRI level in the high dose insulin period for the control subjects $(49 \pm 3 \mathrm{mU} / 1$, mean \pm SEM) was just significantly higher than the corresponding IRI levels in the pre- $(39 \pm 2 \mathrm{mU} / 1)$ and post- $(38 \pm$ $2 \mathrm{mU} / \mathrm{l}$ ) treated diabetic groups (Table $2 ; p<0.05$ ). The basal pre-treated IRG levels $(117 \pm 16 \mathrm{pg} / \mathrm{ml})$ were significantly higher than for the post-treated diabetic group $59 \pm 9 \mathrm{pg} / \mathrm{ml} ; p<0.05)$, but similar to the control group (137 $\pm 46 \mathrm{pg} / \mathrm{ml})$. As expected, IRG levels were 


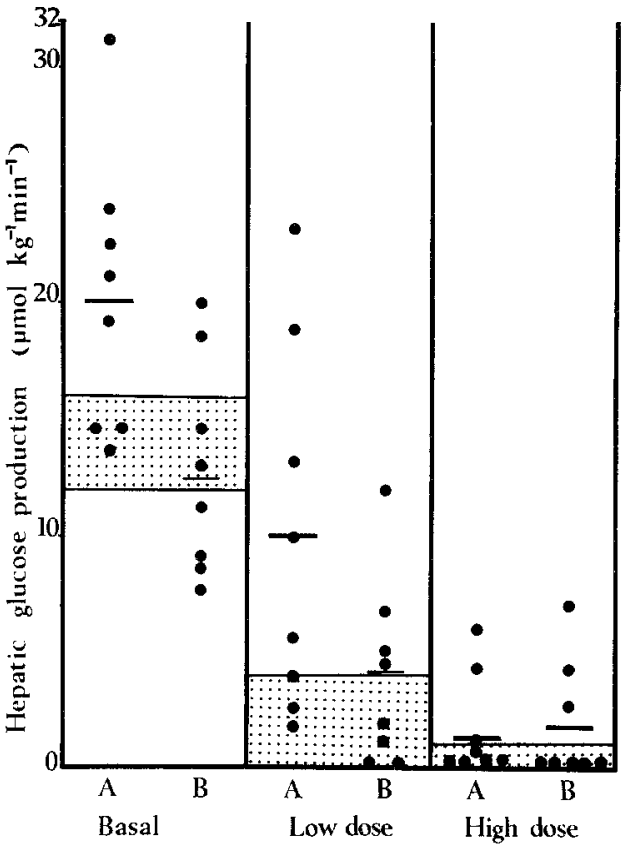

Fig. 2. Hepatic glucose output of diabetic subjects before $(A)$ and after $(B)$ insulin therapy. Values are shown for basal studies and each of the two insulin infusion periods (low dose $=25 \mathrm{mU} \cdot \mathrm{kg}^{-1} \cdot \mathrm{h}^{-1}$; high dose $=40 \mathrm{mU} \cdot \mathrm{kg}^{-1} \cdot \mathrm{h}^{-1}$ ). The mean values are indicated by a horizontal line, and the normal range (mean \pm SD) indicated by the shaded areas

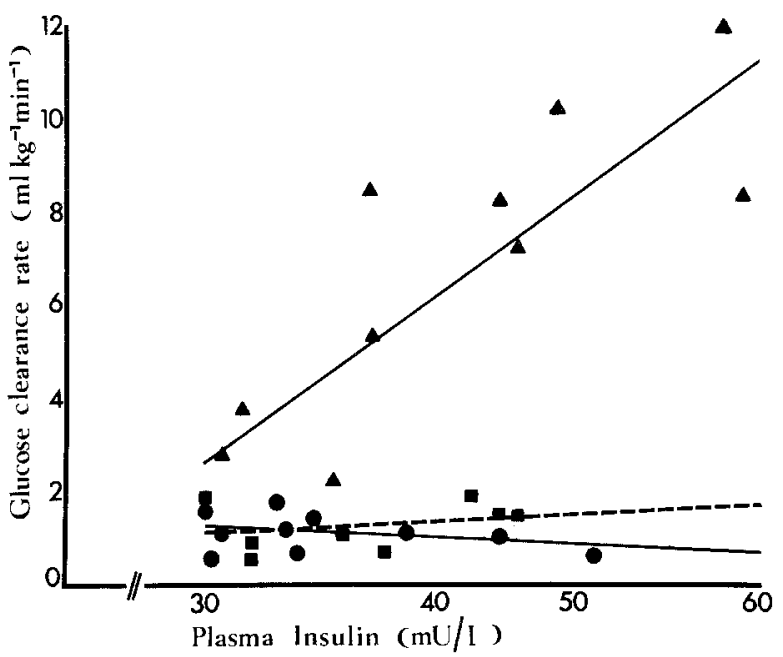

Fig.3. Glucose clearance rate plotted against plasma insulin for all studies with IRI levels $>30 \mathrm{mU} / 1$. The rise in the metabolic clearance rate of glucose with increasing insulin values is significant for normal subjects $(\boldsymbol{\Delta}-\boldsymbol{\Lambda} ; r=0.83 ; p<0.01)$ but no change occurs in diabetic subjects either before (-) or after ( $-\boldsymbol{\square})$ insulin treatment

suppressed significantly in the three experimental groups during the two insulin infusion periods (Table 2).

\section{Hepatic Glucose Production}

Basal hepatic glucose production was elevated in the pre-treated compared with the post-treated diabetic patients $\left(20.0 \pm 2.2\right.$ versus $12.8 \pm 1.7 \mu \mathrm{mol} \cdot \mathrm{kg}^{-1} \cdot \mathrm{min}^{-1}$; $p<0.05$ ), the hepatic glucose production of the latter being similar to control subjects (Table 2, Fig.2). During the lower insulin infusion period, suboptimal hepatic suppression of hepatic glucose production was noted in the pre-treated diabetic group $\left(9.9 \pm 2.9 \mu \mathrm{mol} \cdot \mathrm{kg}^{-1}\right.$. $\min ^{-1} ; 57 \pm 9 \%$ fall), compared with values for the posttreated diabetic patients $\left(4.0 \pm 1.5 \mu \mathrm{mol} \cdot \mathrm{kg}^{-1} \cdot \mathrm{min}^{-1}\right.$; $75 \pm 7 \%$ fall $)$ and control subjects $\left(1.8 \pm 1.0 \mu \mathrm{mol} \cdot \mathrm{kg}^{-1}\right.$ - $\min ^{-1} ; 87 \pm 7 \%$ fall). The hepatic glucose production in the pre-treated diabetic patients was significantly higher than in the post-treated diabetic and control groups ( $p<0.05$; Table 2, Fig. 2). During the higher dose insulin infusion, hepatic glucose production was further suppressed in the three groups, with total suppression occurring in six of the eight pre-treated diabetic subjects. Hepatic glucose production was equally low in all groups during the high dose insulin infusion (Table 2 , Fig. 2). The fasting blood glucose correlated with basal hepatic glucose production $(r=0.50, p<0.05)$, but there was no correlation between the fasting blood glucose and IRG, or between the percentage suppression of hepatic glucose production and basal IRG, or IRG levels during the low dose insulin infusion period.

\section{Glucose Utilization and Metabolic Clearance Rate}

Basal glucose utilization was similar within the three experimental groups (pre-treated diabetics: $14.3 \pm 1.6$, post-treated diabetic patients: $11.0 \pm 1.8$, control subjects: $13.5 \pm 0.8 \mu \mathrm{mol} \cdot \mathrm{kg}^{-1} \cdot \mathrm{min}^{-1}$ ). However, this normal glucose utilization occurred in the presence of significant hyperglycaemia in the diabetic subjects. Glucose utilization did not rise significantly in the diabetic patients or control subjects during the low dose insulin infusion. With the high dose insulin infusion, glucose utilization rose significantly only in the control group $(p<0.001)$. Glucose utilization during the high dose insulin infusion was higher in the pre-treated than the posttreated diabetic patients $(p<0.05)$ but it is noted that glucose levels were also significantly higher in the pretreated group ( 17.0 versus $12.7 \mathrm{mmol} ; p<0.01)$. Glucose utilization in the normoglycaemic control subjects was significantly higher than in either diabetic group for this period $(p<0.001)$.

Comparison of glucose utilization data is difficult, as all studies in the diabetic patients were carried out during marked hyperglycaemia. Therefore the metabolic clearance rate of glucose has been calculated for all subjects with insulin levels greater than $30 \mathrm{mU} / 1$ (Fig.3). In the control subjects a marked increase in metabolic clearance rates occurs with increasing insulin levels $(r=0.83$, $p<0.01)$. The diabetic patients exhibit no such rise $(r=$ 0.15 ). Mean data for insulin levels and glucose clearance are given in Table 2.

\section{Non-esterified Fatty Acids and $\beta$-Hydroxybutyrate}

Basal plasma NEFA levels were elevated in the pretreated diabetic group compared with both the post- 
treated diabetic $(p<0.02)$ and control subjects $(p<$ 0.001 ), but were not raised significantly in the post-treated diabetic patients (Table 2). Following the 25 and $40 \mathrm{mU} \cdot \mathrm{kg}^{-1} \cdot \mathrm{h}^{-1}$ insulin infusions, NEFA levels fell to a similar nadir in the pre-treated $(0.38 \pm 0.06 \mathrm{mmol} / \mathrm{l})$, post-treated diabetic $(0.30 \pm 0.06 \mathrm{mmol} / \mathrm{l})$ and control $(0.33 \pm 0.16 \mathrm{mmol} / \mathrm{l})$ subjects. However, the rate of NEFA decay $\left(\mathrm{t}_{1 / 2}\right)$ post-insulin infusion, was prolonged for the pre-treated group (33 min), compared with the post-treated diabetic $(18 \mathrm{~min})$ and control subjects (20 min). Fasting $\beta$-hydroxybutyrate levels were elevated in the pre-treated and post-treated diabetic patients compared with the control group $(p<0.005)$.

\section{Erythrocyte Receptor Insulin Binding}

The mean basal percentage binding of insulin to the erythrocyte insulin receptor was similar in the pre$(8.98 \pm 1.07 \%)$ and post-treated $(10.38 \pm 1.04 \%)$ diabetic subjects, falling within the normal range (Table 2). Further, the affinity of insulin for its receptor, when the data were re-examined by Scatchard analysis, was also similar in all groups.

\section{Discussion}

It is clear from this study that in poorly controlled Type 2 diabetes hepatic glucose production is elevated, and is suppressed only partially in response to a low dose insulin infusion $[10,23]$. Further elevation of insulin levels, however, results in complete suppression of hepatic glucose production (Fig. 2). As all diabetic subjects were studied during marked hyperglycaemia, it would also appear that under basal conditions, the liver production fails to be suppressed by elevated blood glucose levels [6, $24,25,26]$. We are unable to determine from our studies whether the liver is predominantly failing to respond to insulin, or to hyperglycaemia. It is unlikely that the slightly elevated glucagon levels account for the hepatic glucose overproduction since chronic hyperglucagonaemia in cirrhosis and the glucagonoma syndrome is not associated with increased hepatic glucose production $[13,27]$. Moreover, we could find no correlation between basal IRG levels and basal hepatic glucose production in the diabetic subjects.

Following one week of insulin therapy and good diabetic control, both the basal hepatic glucose production and its suppressibility by low dose insulin return to normal (Fig. 2). Therefore the glucose intolerance of treated Type 2 diabetic subjects is unlikely to be related to either hepatic glucose overproduction or hepatic resistance to insulin.

Another important finding is that glucose disposal in both the uncontrolled and the treated diabetic subjects is markedly impaired. This means that basal glucose utilization is maintained within the normal range only in the presence of profound hyperglycaemia, as noted originally by Soskin and Levine [28], and confirmed by Reaven et al. [29] and De Fronzo et al. [7]. Furthermore, the increase in glucose utilization in the diabetic subjects during the higher dose insulin infusion is small compared with the large rise seen in normoglycaemic control subjects (Table 2). One could speculate that the increased basal hepatic glucose production in the untreated diabetic subjects contributes to maintenance of a sufficient degree of hyperglycaemia to ensure normal basal glucose utilization.

As glucose utilization is known to be largely dependent on the prevailing plasma glucose concentration [30], it is necessary to find a measure of the efficiency of glucose disposal. The metabolic clearance rate of glucose provides a means of standardising data obtained at different blood glucose concentrations. This appears to be valid provided that insulin levels are greater than $30 \mathrm{mU} / 1$ [22] and that glucose concentrations are lower than those causing saturation of the intracellular glucose pathways $(<25 \mathrm{mmol} ;[30,31])$. Thus, the metabolic clearance rate was calculated for all plateau periods with insulin levels $>30 \mathrm{mU} / 1$ and provides striking evidence that the clearance of glucose in Type 2 diabetic subjects, both before and after insulin therapy, is greatly impaired (Fig.3). Thus, a defect in peripheral glucose disposal seems an important mechanism of the glucose intolerance of Type 2 diabetes.

The reason for the decreased glucose disposal is unclear. NEFA levels were elevated in our diabetic subjects and are postulated to inhibit insulin action [32]. However, NEFA values fell in response to the insulin infusion while the metabolic clearance rate failed to rise significantly. Further, during the period of insulin therapy, basal NEFA levels remained normal for several days, but the defect in glucose clearance persisted. Erythrocyte insulin receptor binding characteristics were similar in the diabetic and control subjects both before and after insulin therapy. The failure to find reduced erythrocyte receptor binding, as has been found in monocytes in Type 2 diabetes, may be related to the fact that the group of diabetic subjects studied were insulinopenic $[26,33$, $34]$ or to the fact that oral hypoglycaemic agents were ceased only 3 days before the initial study. However, these receptor binding data are consistent with the suggestion that the defect in glucose clearance is due to a post-receptor defect of glucose metabolism [2].

It is interesting to note that whilst satisfying all other criteria for classification as Type 2 diabetic patients, in that they were maturity onset, had longstanding disease which had been previously controlled by oral agents, and had suffered no episodes of ketoacidosis, our subjects had an impaired insulin response to oral glucose $[35,36]$. This relative hypoinsulinaemia may be one of the causative factors in the impaired glucose clearance, which persisted despite acute insulin infusions, and one week of insulin therapy. Further studies are needed in milder, hyperinsulinaemic Type 2 diabetic subjects [23, 30]. It has also yet to be determined whether a longer period of insulin therapy and good diabetic control will reverse this defect. 
In conclusion, uncontrolled Type 2 diabetes is characterised by excessive basal hepatic glucose production which is relatively insensitive to acute insulin administration, and a marked impairment of glucose disposal. The latter defect appears to be the major contributing factor to the development of glucose intolerance and is not improved by 7 days of insulin treatment. The cause of the decreased metabolic clearance rate of glucose is not known.

Acknowledgements. AN and JP are recipients of National Health and Medical Research Council Scholarships. This work was performed in partial fulfilment of thesis requirements. Presented in part at the European Association for the Study of Diabetes 17th Annual Meeting, Amsterdam, 1981. We wish to thank the Biochemistry Department, St. Vincent's Hospital for the excellent technical assistance and Ms. K. Dawson for her assistance in the preparation of this paper. We are indebted to the Hospital authorities for their permission to publish, and we wish to acknowledge the support received from the John Claude Kellion Foundation.

\section{References}

1. Reaven G, Olefsky $\mathbf{J}$ (1978) The role of insulin resistance in the pathogenesis of diabetes mellitus. Adv Metab Disord 9:313-331

2. Olefsky J (1981) Insulin resistance and insulin action. An in vitro and in vivo perspective. Diabetes 30:148-162

3. Alford F, Martin F, Pearson M (1971) The significance and interpretation of mildly abnormal oral glucose tolerance. Diabetologia 7:173-180

4. Kalant N, Csorba T, Heller N (1963) Effect of insulin on glucose production and utilization in diabetes. Metabolism 12:1100-1111

5. Myers J (1950) Net splanchnic glucose production in normal man and in various disease states. J Clin Invest 29:1421-1429

6. Bearn A, Billing B, Sherlock S (1951) Hepatic glucose output and hepatic insulin sensitivity in diabetes mellitus. Lancet 2: 698-701

7. DeFronzo R, Deibert D, Hendler R, Felig P, Soman V (1979) Insulin sensivitivity and insulin binding to monocytes in maturity-onset diabetes. J Clin Invest 63: 939-946

8. Forbath N, Hetenyi Jr G (1966) Glucose dynamics in normal subjects and diabetic patients before and after a glucose load. Diabetes 15: 778-789

9. Bowen $H_{3}$ Moorhouse $J$ (1973) Glucose turnover and disposal in maturity-onset diabetes. J Clin Invest 52: 3033-3045

10. Kimmerling G, Javorski W, Olefsky J, Reaven G (1976) Locating the site(s) of insulin resistance in patients with nonketotic diabetes mellitus. Diabetes 25: 673-678

11. Hall SE, Saunders J, Sonksen PH (1979) Glucose and free fatty acid turnover in normal subjects and in diabetic patients before and after insulin treatment. Diabetologia 16: 297-306

12. Steele R, Wall J, de Bodo RC, Altszuler N (1956) Measurement of size and turnover rate of body glucose pool by the isotope dilution method. Am J Physiol 187: 15-24

13. Proietto J, Alford F, Dudley F (1980) The mechanism of carbohydrate intolerance of cirrhosis. J Clin Endocrinol Metab 51: 1030-1036

14. Alford F, Bloom S, Nabarro J(1977) Glucagon levels in normal and diabetic subjects: use of a specific immunoabsorbent for glucagon radioimmunoassay. Diabetologia 13:1-6

15. Altszuler N, Bardai A, Bjerkes C, Gottlieb B, Steele R (1975) Glucose turnover values in the dog obtained with various species of labelled glucose. Am J Physiol 229: 1662-1667

16. Albano J, Ekins R, Maritz G, Turner R(1972) A sensitive precise radioimmunoassay of serum insulin relying on charcoal separation of bound and free moieties. Acta Endocrinologia 70:487-509
17. Carruthers M, Young D (1973) Free fatty acid estimation by a semiautomated fluorimetric method. Clin Chim Acta 49:341-343

18. Williamson D, Mallanby J, Krebs H (1962) Enzymic determination of $\mathrm{D}(-)-\beta$-hydroxybutyric acid and acetoacetic acid in blood. Biochem J 82: 190-196

19. Gambhir K, Archer J, Carter L (1977) Insulin radioreceptor assay for human erythrocytes. Clin Chem 23:1590-1595

20. Steele R (1959) Influences of glucose loading and injected insulin on hepatic glucose output. Ann NY Acad Sci 82: 420-430

21. Riggs DA (1963) The mathematical approach to physiological problems. Williams \& Wilkins, Baltimore, pp 913-929

22. Proietto J, Harewood M, Aitken P, Nankervis A, Caruso G, Alford $F$ (1982) Validation of a practical in vivo insulin dose-response curve in man. Metabolism 31:354-361

23. Best J, Judzewitsch R, Pfeifer M, Beard J, Halter J, Porte D, Jr (1982) The effect of chronic sulfonylurea therapy on hepatic glucose production in non-insulin dependent diabetes. Diabetes (in press)

24. Brown P, Tompkins C, Juul S, Sonksen P(1978) Mechanism of action of insulin in diabetic patients: a dose related effect on glucose production and utilization. Br Med J 1: 1239-1242

25. Sacca L, Hendler R, Sherwin R (1978) Hyperglycaemia inhibits glucose production in man, independent of changes in glucoregulatory hormones. J Clin Endocrinol Metab 47:1160-1163

26. Liljenquist J, Mueller G, Cherrington A, Perry J, Rabinowitz D (1979) Hyperglycaemia per se (insulin and glucagon withdrawn) can inhibit hepatic glucose production in man. J Clin Endocrinol Metab 48: 171-175

27. Nankervis A, Proietto J, Ng K, Alford F, Larkins R (1981) The metabolic effects of chronic hyperglucagonaemia. Clin Endocrinol $15: 325-333$

28. Soskin S, Levine R (1937) A relationship between the blood sugar level and the rate of sugar utilization, affecting the theories of diabetes. Am J Physiol 120: 761-770

29. Reaven G, Silvers A, Farquhar J (1970) Study of the relationship between plasma insulin concentration and efficiency of glucose uptake in normal and mildly diabetic subjects. Diabetes 19: 571-578

30. Davis B, Bernstein R, Kolterman O, Olefsky J, Reaven G (1978) Defect in glucose removal in nonketotic diabetic patients with fasting hyperglycaemia. Diabetes 28:32-35

31. Olefsky J, Farquhar J, Reaven G (1973) Relationship between fasting plasma insulin level and resistance to insulin-mediated glucose uptake in normal and diabetic subjects. Diabetes 22: 507-513

32. Randle P, Garland P, Hales C, Newsholm E, Denton R, Pogson C (1966) Interactions of metabolism and the physiological role of insulin. Recent Prog Horm Res 22:1-48

33. Olefsky J, Kolterman O (1981) Mechanisms of insulin resistance in obesity and non-insulin-dependent (Type 2) diabetes. Am J Med $70: 151-168$

34. Beck-Nielson H, Pedersen O, Sorensen N (1980) Effects of dietary changes on cellular insulin binding and in vivo insulin sensitivity. Metabolism 29:482-487

35. Reaven G, Miller R (1968) Study of the relationship between glucose and insulin responses to an oral glucose load in man. Diabetes 17: $560-567$

36. Zimmet P, Whitehouse S, Alford F, Chisholm D (1978) The relationship of insulin response to a glucose stimulus over a wide range of glucose tolerance. Diabetologia $15: 23-27$

Received: 9 October 1981

and in revised form: 24 April 1982

Dr. A. Nankervis

Endocrine Unit

St. Vincent's Hospital

Victoria Parade

Fitzroy, Victoria 3065

Australia 